Nordisk Tidsskrift for Kriminalvidenskab 2006

\title{
DOLUS NORDICUS
}

AV FORSKARE, JUR.DR. JUSSI MATIKKALA

The Nordic countries have a history of intensive interaction, not least in the field of criminal law on both practical questions and theoretical matters. In 1960, an important meeting on Nordic criminal law was held in Reykjavik. One of the topics discussed was intent and mistake of law. At that time, criminal intent was not yet defined in the criminal codes of Denmark, Finland, Norway and Sweden. The current paper discusses the later development of the law on criminal intent in these countries, especially in Finland.

\section{Allmänt}

År 1960 hölls i Reykjavik det 22 Nordiska juristmötet. Ett av diskussionsämnena var "Forsett og rettsvillfarelse i strafferetten". Det fördes en ivrig diskussion kring ämnet. På den tiden var fältet ganska öppet. Lagstiftaren hade inte vågat sig särskilt långt på området. ${ }^{1}$ Från år 1962 är det s.k. Helsingfors-avtalet, enligt vilket de nordiska länderna borde eftersträva enhetliga bestämmelser om brott och brottspåföljder. I den här presentationen behandlas rättsutvecklingen i Danmark, Finland, Norge och Sverige. Härvid kan jag inte försöka gå djupt in på t.ex. rättsdogmatikens prestationer utan måste hålla mig på ett ganska allmänt plan.

Uppsåtsproblematiken hör till straffrättens gemensamma förmögenhet. Frågorna har behandlats åt olika håll. Man kan skilja mellan olika uppsåtsdiskussioner: de nationella, den nordiska, den nordisk-tyska, den europeiska och den internationella. De två sistnämnda har föranletts av den starka framväxten och utvecklingen av europeisk och internationell straffrätt. Subjektiva tillräknanderegler har såväl konstruerats inom europeiska straffrättsprojekt (t.ex. Corpus juris och Europa-Delikte) som antagits på internationell nivå, i spetsen Romstadgan för Internationella brottmålsdomstolen. Man måste kanske någon gång inom europeisk straffrätt t.ex. välja mellan tudelningen uppsåt - oaktsamhet och den engelska tredelningen intention - recklessness - negligence. Romstadgans definition t.ex. av subjektiva rekvisit (artikel 30) har varit föremål för olika tolkningar (se också artikel 32 om faktisk villfarelse och rättsvillfarelse). I den här framställningen måste den intressanta europeiska och internationella synvinkeln i uppsåtsproblematiken lämnas åsido.

\footnotetext{
* Title in English: Dolus nordicus. Original in Swedish.
} 
Förenklat kan det sägas finnas två huvudfrågor kring uppsåtet: 1) vilket är uppsåtets innehåll och 2) vem har till uppgift att bestämma över detta innehåll. Rättsläget kan förändras eller bevaras i förhållande till bägge frågeställningarna/ hänseendena.

Minst sex olika allmänna dimensioner kan anses inverka på uppsåtsansvaret. Uppsåt innehåller alltid något slags kognitiv sida. Som höjddimension kan kallas frågeställningen om hur sannolik man måste hålla den relevanta saken för att uppsåtet ska vara förhanden i förhållande till den. En annan sak är att t.ex. en volitiv sida också kan ingå i uppsåtet. Dessutom kan man, för det andra, fråga sig hur framme i medvetandet den relevanta saken måste vara för att uppsåt ska anses föreligga. Krävs det ett "Daran-Denken" eller är det nog med någon sorts latent eller till och med potentiell uppfattning om saken $?^{2}$ Detta kan kallas uppsåtets djupdimension. En tredje frågeställning är hur långt, på brottsbegreppets nivå, uppsåtet ska sträcka sig; ska uppsåtet förutom det objektiva som uppfyller en brottsbeskrivning också täcka t.ex. icke-förhandenvaron av en ansvarsfrihetsgrunds motsvarande material eller gärningens rättstridighet? En närbesläktad fråga är hur långt in i objektet och dess olika egenskaper uppsåtet måste sträcka sig. Omvänt är det fråga om skiljandet av olika villfarelsetyper från varandra. För det femte måste man räkna med att uppsåtet åtminstone i någon mån kan variera från brottstyp till brottstyp. Det krävs kanske högre sannolikhetsinsikt vid vissa brottstyper eller -rekvisit än vid andra. Eventuellt förutsätts i något sammanhang en mera aktuell medvetenhet medan det kanske räcker med någon sorts "Mitbewußtsein" i ett annat. Bland uppsåtets materiella dimensioner eller element kan somliga vara mindre flexibla än andra. Så kan det vara en strukturell principfråga om rättstridigheten hör till uppsåtets objekt eller inte. I alla fall är det tänkbart att uppsåtsansvaret ser på olika punkter något olikt ut beroende på vilket innehåll de element det är sammansatt av har.

För det sjätte har vi den processuella sidan. Att känna det materiella uppsåtet är inte ännu hela sanningen. För att veta hur brett uppsåtsansvar i verkligheten är måste vi också ha svar på bl.a. sådana frågor som vem har bevisbördan och hur högt beviskravet är? I straffprocessen utgår man principiellt ifrån att det är åklagaren som har bevisbördan. Han måste bevisa brottsförutsättningarna (till vilka bl.a. uppsåtet hör) så säkert att svarandens skuld ligger utom rimligt tvivel. Detta är den principiella regeln. Men å andra sidan är vissa saker lättare att bevisa än andra. Det brukar framföras, att det är synnerligen svårt att styrka subjektiva rekvisit. Det är svårt att se in i huvudet på andra. Också inom de subjektiva rekvisiten finns skillnader härvid. Bevismetoderna och bevisproblematiken kan ligga något olika till vid bevisningen t.ex. av att svaranden: 
- haft för avsikt att göra $\mathrm{x}$

- haft för avsikt att åstadkomma följden F

- har trott att hans gärning förorsakar följden F

- har trott att en viss faktisk omständighet $\mathrm{O}$ föreligger

- har trott att en viss rättsfråga förhåller sig på ett visst sätt.

Man måste kunna skilja mellan materiella och rättsliga frågor. Annars blir det kaotiskt. En annan sak är att bevisdimensionen måste tas i beaktande när man formulerar materiellträttsliga regler. T.ex. vid formuleringen av uppsåtsregler måste bevismöjligheterna hållas för ögonen. Bland i övrigt lika bra uppsåtsmodeller lönar det sig att välja den, vars förutsättningar bäst går att bevisa med tillbudsstående lagliga bevismedel.

Sedan finns det specialfrågor. Vilken betydelse har omständigheter såsom rus, mentala problem, höggradig affekt och dylikt för uppsåtsbedömningen? Modifierar sådana faktorer annars gällande materiella och/eller processuella regler?

Det förekommer också olika andra subjektiva element i brottsbeskrivningarna. Ingå kan t.ex. vissa avsikter och syften (bl.a. s.k. överskjutande avsiktsrekvisit) eller element om vetskap, motiv, planmässighet, överlägg, berått mod och annat. Det kan naturligtvis någon gång vara smaksak om man kategoriserar ett avsiktsrekvisit eller vetskapselement som kvalificerade uppsåtskrav eller om man hellre kallar dem andra subjektiva element. ${ }^{3}$

\section{Danmark, Sverige, Norge och Finland}

I Danmark synes rättsläget ha bevarats mest oförändrat. I lagen regleras främst när uppsåt krävs och när det är nog med oaktsamhet (strl 19 §). Ansvaret för bestämmandet av uppsåtets innehåll ligger dock på andra rättskällor. I kapitel 10 om straffbestämning intogs en bestämmelse om egentlig rättsvillfarelse som straffnedsättningsgrund ( $\operatorname{strl} 84 \S$ ). Regleringen reviderades för ett par år sedan (strl 82-83 §). Sådan villfarelse kan till och med leda till straffbortfall men inte till ansvarsfrihet. En oegentlig rättsvillfarelse har samma - dvs uppsåtsuteslutande - verkan som faktisk villfarelse. Allmänna materiella uppsåtsregler tillämpas i princip också när någon misstagit sig om fakta på grund av rus. Vad gäller gränsdragningen mellan uppsåt och oaktsamhet, har man traditionellt opererat såväl med ett sannolikhetsuppsåt som viljemodeller. Förarbeten till 1930 års straffelov har spelat en betydande roll. Dessa går ut på - vid sidan av sannolikhetsuppsåtet - den hypotetiska viljeteorin. 
Sannolikhetsuppsåtets ställning som uppsåt är inte omtvistat. Det räcker nuförtiden med ett enkelt sannolikhetsuppsåt, dvs beträffande sannolikhetsgraden är det nog med en sannolikhetsövervikt (mera än 50 \%). Ställningen av dolus eventualis i form av hypotetisk och positiv viljeteori är inte lika klar. Särskilt gäller detta den hypotetiska varianten, vars giltighet synes ha främjats av 1930 år strafflags förarbeten. Positiv viljeteori har använts i vissa senare prejudikat. Prejudikaten synes inte heller bestrida den hypotetiska variantens giltighet. Højesteret har i U $1992.455 \mathrm{H}$ ansett, att dolus eventualis bör användas med varsamhet (vad man menar med detta är kanske inte helt klart). Allt i allo har dolus eventualis en supplerande funktion i uppsåtet. Likgiltigheten verkar inte utgöra något särskilt viktigt tema i dolus eventualis-diskussionen. ${ }^{4}$

I den svenska brottsbalken från år 1962 togs en bestämmelse om när uppsåt krävs (BrB 1:2). En definition av uppsåtet antogs däremot inte. I paragrafens andra stycke finns en regel om det självförvållade rusets betydelse (BrB 1:2.2). Regeln har gett upphov till olika tolkningar. ${ }^{5}$ En också för uppsåtet betydelsefull grundval i lagen var avskaffandet av tillräkneligheten som straffansvarsförutsättning.

En definition enligt den hypotetiska viljeteorin som gränsdragningsmodell föreslogs i SOU 1923:9, och även om förslaget inte godkändes blev ställningstagandet i förarbeten mycket betydelsefullt. Uppsåtets nedre gräns drogs länge enligt den hypotetiska viljeteorin. Modellen blev stundom hårt kritiserad men överlevde ändå länge som det enda gränsdragningsinstrumentet. Ett sannolikhetsuppsåt, som varit en självklar uppsåtsform i både dansk och norsk rätt, accepterades inte. Tvärtom tackade svenska HD två gånger nej till sannolikhetsuppsåtet (NJA 1959 s. 63 och 1980 s. 514). Svensk rätt var mycket trogen mot den hypotetiska viljeteorin. Redan på 1970-talet började man i praxis dock också argumentera med gärningspersonens (totala) likgiltighet. ${ }^{6}$

I Sverige har man stegvis reviderat de allmänna lärorna. År 1994 infördes i samband med revisionen av ansvarsfrihetsgrunderna en bestämmelse om straffrättsvillfarelse (BrB 24:9). Därefter förberedde Straffansvarsutredningen (SOU 1996:185) ett förslag till uppsåtsdefinition. Man ville bli av med den kritiserade hypotetiska viljeteorin och ansåg att detta görs lämpligast genom lagstiftning. Likgiltighetsuppsåtet ansågs bättre än den hypotetiska viljeteorin, men det hade förekommit en viss diskussion huruvida likgiltighetsuppsåtet verkligen var en egen gränsdragningsform eller om det bara var fråga om ett annat sätt att uttrycka det hypotetiska eventuella uppsåtet. Sannolikhetsuppsåtet hade avvisats i praxis. I detta läge föreslog man en annan kognitiv modell: insiktsuppsåtet. Den föreslagna bestämmelsen i $\mathrm{BrB}$ 1:2.2 lydde: ”En gärning begås uppsåtligen om den är avsiktlig eller om den motsvarar vad gärningsmannen har insett, uppfattat eller antagit om den”. Förslaget accepterades emellertid inte och bol- 
len kastades tillbaka till praxis. HD gav först ett inte utslagsgivande prejudikat (NJA 2002 s. 449) men i och med NJA 2004 s. 176 togs steget fullt ut mot ett likgiltighetsuppsåt. ${ }^{7}$ Senare domar gällande såväl följd- som omständighetsuppsåt befäster den ändrade kursen (NJA 2004 s. 479, 2004 s. 519, 2004 s. 702 , 2005 s. 732).

I Norge tog lagstiftaren i 1902 års straffelov en bestämmelse om när uppsåt krävs (strl 40 §) samt en regel om faktisk villfarelse (strl 42 §) och rättsvillfarelse (strl 57 §). En positiv definition av uppsåtet antogs ej. Oegentliga rättsvillfarelser har bedömts enligt $42 \S$. En egentlig rättsvillfarelse har betytt ansvarsfrihet, om den var ursäktlig (aktsam). Om medvetslöshet på grund av självförvållat rus stadgas i strl $45 \S$.

Liksom i Danmark anses sannolikhetsuppsåt med överviktsgränsen vara en säker form av uppsåt. Dolus eventualis -varianternas ställning har varit mera oklar. Hypotetisk viljeteori anses ha blivit avvisat genom Rt 1991 s. 600, medan accepterandet av den positiva viljeteorin ansågs framgå bl.a. av Rt 1980 s. 979. Lagstiftaren har emellertid nyligen tagit ställning till uppsåtets innehåll och villfarelseproblematiken.

En totalrevision av straffeloven inleddes 1980. Också uppsåtet skulle definieras. Enkelt sannolikhetsuppsåt skulle givetvis fortfarande vara en del av uppsåtet. Däremot gick meningarna isär i frågan om det dessutom fanns behov för dolus eventualis eller inte. En av riskerna med avskaffandet av dolus eventualis ansågs vara att sannolikhetsuppsåtets sannolikhetskrav skulle kunna komme att sänkas. Som exempel på brott där den positiva innvilgelsesteorin skulle kunna behövas, nämndes brott mot liv och hälsa, narkotikabrott och organiserad kriminalitet. Slutligen togs en variant av positiv viljeteori med i lagen, och den antagna men ännu inte i kraft trädda straffelov $22.1 \S$ fick följande form: "Forsett foreligger når noen a) handler med hensikt om å oppfylle gjerningsbeskrivelsen i et straffebud, b) handler med bevissthet om at handlingen sikkert eller mest sannsynlig oppfyller gjerningsbeskrivelsen i et straffebud, eller c) regner det som mulig at handlingen oppfyller gjerningsbeskrivelsen i et straffebud, og bestemmer seg for å foreta handlingen selv om gjerningsbeskrivelsen med sikkerhet eller mest sannsynlig skulle bli oppfylt". ${ }^{8}$

I den likaledes antagna strl $25 \S$ regleras faktisk uvitenhet och i strl $26 \S$ rettsuvitenhet ("den som på handlingstidspunktet er ukjent med at handlingen er ulovlig, straffes når uvitenheten er uaktsom"). Stadgandena innebär, att oegentliga rättsvillfarelser bedöms enligt strl $26 \S$. Det kan ses som en skärpning, men en motvikt kan nås därigenom att aktsamhetskravet är mildare vid oegentlig än vid egentlig rättsokunskap. Om rättsokunskapen är oaktsam, finns det visst utrymme för straffbortfall (strl $61 \S) .{ }^{9}$ Beträffande rusets betydelse vidareförs den reglering, 
som antogs 1997 som strl 40 och $42 \S$. Det ses bort från okunskap om faktiska omständigheter, om skälet till okunskapen var självförvållat rus. I sådana situationer bedöms gärningspersonen som om han hade varit nykter $(\operatorname{strl} 25.3 \S) .{ }^{10}$

I finsk SL från år 1889 förekom varken regler om uppsåt eller villfarelse. Fram till sjuttiotalet var positiv viljeteori inklusive likgiltighetsuppsåt den förhärskande gränsdragningsmodellen, åtminstone i doktrinen. Den hypotetiska varianten har däremot inte spelat någon större roll i Finland. 1972 inleddes en totalrevision av SL. Straffrättskommittén rekommenderade i sitt betänkande från år 1976 en övergång till sannolikhetsuppsåtet samt uppsåtets definierande i lagen. Praxis (från och med 1978) var vacklande och brokig, men särskilt på 1990-talet förstärkte sannolikhetsuppsåtet sin ställning - främst vad gäller uppsåt att döda.

I strafflagsrevisionen var frågan - såtillvida i likhet med Norge - huruvida man utöver ett sannolikhetsuppsåt också borde ta med någon form av positiv viljeteori. I sitt förslag från år 2000 föreslog strafflagsprojektet - tillsatt år 1980 för att föra revisionen vidare efter straffrättskommittén - en definition där både sannolikhetsuppsåt och ett godkännandeuppsåt var med. Sistnämnda ströks likväl efter HD:s utlåtande och togs inte med i RP 44/2002. ${ }^{11}$ Dessutom fanns regler om rekvisitvillfarelse, förbudsvillfarelse och villfarelse över ansvarsfriande omständighet med i RP:n. I riksdagen spelades dock den sista akten. Efter att ha hört sakkunniga föreslog nämligen lagutskottet i sitt betänkande LaUB 28/2002 att uppsåtsdefinitionens tillämpningsområde begränsas att gälla enbart följduppsåt. Utskottet motiverar s. 9-10: "Definitionen av [följd] uppsåt är inte lika svår att fastslå eller lika omtvistad som [omständighets] uppsåt, där formerna varierar enligt brottstyp. Den föreslagna bestämmelsen har ansetts särskilt misslyckad med avseende på omständighetsuppsåt vid ekonomiska brott och det har ansetts att definitionen [höjer] ${ }^{12}$ uppsåtströskeln. Utskottet föreslår därför att i paragrafen endast föreskrivs om följduppsåt. Frågan om omständighetsuppsåt kommer att prövas i rättspraxis, varvid bestämmelsen om rekvisitvillfarelse bör beaktas". Så fick vi till slut följande uppsåts- och villfarelseregler, som trädde i kraft $\mathrm{i}$ början av 2004:

3:6 Uppsåt. Gärningsmannen har uppsåtligen orsakat en följd som omfattas av en brottsbeskrivning, om han eller hon har avsett att orsaka följden eller ansett följden vara säker eller övervägande sannolik. Följden har likaså orsakats uppsåtligen, om gärningsmannen ansett att den med säkerhet har samband med den följd han eller hon avsett.

4:1 Rekvisitvillfarelse. Om gärningsmannen vid tidpunkten för gärningen inte är medveten om att samtliga omständigheter som förutsätts för brottsbeskrivningsenlighet föreligger eller om gärningsmannen misstar sig om en sådan omständighet, är gärningen inte uppsåtlig. Ansvar för ett oaktsamhetsbrott kan dock komma i fråga enligt bestämmelserna om straffbar oaktsamhet. 
4:2 Förbudsvillfarelse. Tror gärningsmannen felaktigt att en gärning är tilllåten, är han eller hon fri från straffansvar, om denna villfarelse skall anses vara uppenbart ursäktlig med anledning av att

1) offentliggörandet av en lag är behäftat med brister eller fel,

2) innehållet i en lag är speciellt svårbegripligt,

3) en myndighet har givit felaktiga råd, eller

4) det föreligger någon annan jämförbar omständighet.

4:3 Villfarelse om en ansvarsfriande omständighet. Om en gärning inte har en i 4-6 $\S$ avsedd ansvarsfrihetsgrund men gärningssituationen, sådan som gärningsmannen med fog uppfattade den, hade varit förknippad med en sådan grund, bestraffas han eller hon inte för ett uppsåtligt brott. Ansvar för ett oaktsamhetsbrott kan dock komma i fråga enligt bestämmelserna om straffbar oaktsamhet.

I finsk rätt finns således nuförtiden en klar tudelning i följduppsåt och omständighetsuppsåt. Det blev dessutom inte så att vid den förra används en viss gränsdragningsmodell och vid den senare en annan, utan bara vid den förra ansågs tiden mogen för en gränsdragning enligt någon modell medan man vid den senare skulle nöja sig med något slags måhända från brottstyp till brottstyp varierande gränsdragning - dock under beaktande av SL 4:1.

Den sista meningen i SL 3:6 täcker det s.k. villkorliga säkerhetsuppsåtet. En terrorist försöker få en bomb med på ett flyg. Hans avsikt är att döda ett visst statsöverhuvud som ska vara med på flyget. Han förstår, att om bomben exploderar, så omkommer också alla andra. Samtidigt inser han, att säkerhetsåtgärderna är så pass effektiva, att attentatet kommer att lyckas bara med $5 \%$ sannolikhet. Med hänsyn till andras än statsöverhuvudets död har han varken avsikts- eller säkerhetsuppsåt enligt SL 3:6, utan här tillämpas paragrafens sista mening. I några andra länder kan typfallet anses omfattas av direkt eller indirekt uppsåt (Sverige).

På villfarelsefronten opererar man alltså inte bara med t.ex. en indelning i en uppsåtsuteslutande och icke-uppsåtsuteslutande villfarelsetyp utan här gäller en tredelning. Lösningen påminner om den tyska. En SL 4:1-villfarelse betyder att uppsåtet saknas, medan en 4:3-villfarelse betyder (bara) att man inte bestraffas för ett uppsåtligt brott. Fråga är dock om ansvarsfrihet och inte bara domseftergift. Rusets betydelse för tillräkenbarheten (uppsåt och oaktsamhet) regleras inte i något lagrum. Enligt gammalt mönster lagstiftades bara om rusets förhållande till tillräkneligheten (SL 3:4.4). ${ }^{13}$ 


\section{Exkurs: några problem och tolkningar av det finska rättsläget}

Från början har det varit oklart, hur hög sannolikhet det finska sannolikhetsuppsåtet förutsätter. Bland skälen till detta är att det finskspråkiga sannolikhetsattributet "varsin" är mycket vagt och tillåter således ett betydligt tolkningsutrymme. I straffrättskommitténs betänkande, $i$ vilket föreslogs en övergång från positiv viljeteori till sannolikhetsuppsåt, sägs att "gränsen mellan uppsåt och vållande borde justeras sålunda, att en effekt vars inträdande gärningsmannen ansåg vara uppenbart osannolik inte skulle kunna tillräknas honom som uppsåtlig, försåvitt han inte avsåg att framkalla ifrågavarande effekt” (KM 1976:72 s. 180). År 1989 ville strafflagsprojektet införa en lex specialis om uppsåt att döda och skada hälsa, där det av straffrättskommittén använda uttrycket "varsin todennäköinen" förklarades betyda "högst sannolik" och "nästan säker". Ingen kan heller säga, vad samma finska uttryck i verkligheten har betytt i HD:s prejudikatur. "Synnerligen sannolik" har varit en ganska vanlig översättning (finskspråkiga HD-prejudikatens rubriker översätts till svenska). I den svenskspråkiga RP 44/2002 sägs, att HD dömt för dråp när gärningspersonen hållit döden för "högst sannolik". "Synnerligen sannolik" och "högst sannolik" tyder väl på en klart högre sannolikhet än en enkel $51 \%$-sannolikhet. Skulle man verkligen använda sig av kriteriet "högst sannolik" skulle man sällan kunna döma för (försök till) dråp i det rätt vanliga fallet att gärningspersonen utdelar ett kraftigt knivhugg mot offrets överkropp. ${ }^{14}$ Som läsaren har hunnit erfara utgörs slutligen nämnda finska uttrycks svenska motsvarighet i SL 3:6 av "övervägande sannolik".

Tyvärr ges sannolikhetsuppsåtet i motiven vad jag kan se två innehåll. Det sägs för det första att det ska vara detsamma som i HD:s prejudikat. Men det sägs också att det betyder att gärningspersonen inser att följden snarare inträffar än inte gör det. Det första verkar nästan som en blancofullmakt att göra "allt som hittills". Det senare tyder på ett enkelt sannolikhetsuppsåt. Det är olyckligt att det här inte kunde göras klart. För min del har jag av legalitets-, klarhets- och kontrollerbarhetshänsyn förespråkat det senare alternativet, dvs. att man har goda skäl att förstå SL 3:6 som innehållande ett enkelt sannolikhetsuppsåt. Annars har sannolikhetsuppsåtet inget klart innehåll, vilket gör att en rationell diskussion - t.ex. från svarandens sida - om uppsåtskriterierna är uppfyllda i en viss situation, är mer eller mindre utesluten. Härtill kommer, att det valda svenska lagtextuttrycket - övervägande sannolik - knappast tillåter att underskrida det enkla sannolikhetsuppsåtets förutsättningar. ${ }^{15}$

Som ovan redan framkommit gäller SL 3:6 bara följduppsåtet. Lagutskottet ville att man inte skulle vara bunden till sannolikhetsuppsåtet i fråga om uppsåtet rörande omständigheter. Särskilt befarades, att uppsåtströskeln vid ekonomiska brott skulle höjas. Lagutskottet hade underrättats att man i rättspraxis vid uppsåtsbedömningen av ekonomiska brott använt sig av t.ex. likgiltighetsresonemang samt till och med opererat med plikten att ta reda på saker. Hur ser alltså det finska 
omständighetsuppsåtet ut i dag? Enligt lagutskottet kommer omständighetsuppsåtet att prövas i praxis, varvid SL 4:1 bör beaktas. Enligt SL 4:1 är brottet inte uppsåtligt om gärningspersonen "inte är medveten" om att relevanta omständigheter föreligger. Frågan lyder: är det med beaktande av den citerade ordalydelsen i SL 4:1 möjligt att låta en lägre sannolikhetsinsikt än vid SL 3:6 (övervägande sannolik) vara tillräcklig för omständighetsuppsåtet? Ett jakande svar är enligt mitt förmenande åtminstone inte uppenbart. Anser man det här vara möjligt att underskrida det enkla sannolikhetsuppsåtets krav måste andra gränsdragningsinstrument användas. Blotta riskinsikten är medveten oaktsamhet. ${ }^{16}$

Villfarelsereglerna väcker i övrigt vissa frågor. En är gränsdragningen mellan rekvisitvillfarelse och förbudsvillfarelse när det är fråga om gärningspersonens rättsliga uppfattningar. För det andra, i SL 4:2 om förbudsvillfarelse talas enbart om felaktig, däremot inte om bristande uppfattning om gärningens tillåtlighet. En vidare fråga är hur kvalifikationen "med fog" ska tolkas i putativbestämmelsen SL 4:3. Eftersom lagrummet dessutom explicit hänvisar till bara vissa ansvarsfrihetsgrunder (SL 4:4-6 dvs rättfärdigande och ursäktande nödvärn, nödtillstånd och användning av maktmedel), kan man fråga sig vilken villfarelseregel ska tillämpas på villfarelser angående andra, t.ex. självtäkt (tvångsmedelslagen 1:2a) och envars rätt att gripa (tvångsmedelslagen 1:1).

Finska HD har nyligen gett bl.a. följande avgöranden där uppsåtsfrågor aktualiserades:

HD 2005:126. En reservist hade underlåtit att infinna sig vid en repetitionsövning, vilket hade berott på att han misstagit sig om tidpunkten för övningen. Därför hade han inte gjort sig skyldig till olovlig frånvaro, som endast är straffbar vid uppsåt, och inte heller till uppsåtligt tjänstgöringsbrott. Eftersom reservisten inte med tillräcklig omsorg försäkrat sig om tidpunkten för övningen dömdes han till straff för tjänstgöringsbrott av oaktsamhet.

HD 2006:10. Utan att försöka förvissa sig om sanningsenligheten i de uppgifter som han lämnade, hade A gjort en begäran om förundersökning till polisen och en barnskyddsanmälan till socialmyndigheterna, i vilka antyddes att B gjort sig skyldig till sexualbrott och andra brott. På de grunder som framgår av Högsta domstolens dom ansågs A ha kränkt B:s ära.

HD 2006:26. En skattskyldig hade underlåtit att i sin skattedeklaration uppge överlåtelsevinsterna för värdepapper han sålt. Fråga om han gjort sig skyldig till skattebedrägeri (omröstning).

I alla har bevisfrågorna spelat en roll vilket bör hållas i minnet när man tolkar formuleringarna. Fallen kan naturligtvis inte kommenteras här utförligt. I det första hade reservisten av misstag antecknat felaktig tidpunkt för en repövning i sin almanacka. Det är klart att han inte gjorde sig skyldig till uppsåtlig olovlig 
frånvaro. I det andra var det fråga om bl.a. antydning om incest. Gärningspersonen hade agerat som representant för en barnskyddsförening. Han hade tre månader före gärningarna dömts för likadant beteende. Det är klart klandervärt att inte förvissa sig om sådana uppgifters sanningsenlighet, men för uppsåtet avgörande borde vara om man varit medveten om att de inte är sanna. I skattebedrägerifallet var svaranden expert i skatterätt. Överlåtelsevinsten var drygt 87000 euro. Med en mycket stor sannolikhet (kanske $90 \%$ ) informerar värdepappersmäklaren beskattaren om en dylik överlåtelse, vilket också svaranden visste. Svaranden förklarade att hans livssituation hade varit sådan att han inte hade kunnat sköta sina ärenden. Majoriteten ansåg varken avsiktsuppsåt eller sannolikhetsuppsåt bevisat och frikände svaranden.

På grund av gamla och nya öppna frågor och oklarheter i det finska uppsåtsrättsläget förutsätts här av HD en hög profil och en kritisk analys. ${ }^{17}$

\section{Dolus nordicus?}

Jämför man norskt och finskt följduppsåt och vågar man anta att det senare förutsätter minst ett enkelt sannolikhetsuppsåt, kan man säga att det norska följduppsåtet är mera omfattande eftersom det också kan basera sig på faktisk dolus eventualis. Danskt följduppsåt liknar det norska, men läget kan vara något mera öppet, eftersom det saknas en legaldefinition. Dessutom är den hypotetiska viljeteorin inte längre gällande uppsåtsform i Norge. Det svenska likgiltighetsuppsåtet torde i princip kunna vara såväl snävare som bredare än ett enkelt sannolikhetsuppsåt.

Omständighetsuppsåtets nedre gräns torde i princip vara likadant som följduppsåtets i Danmark, Norge och Sverige. I Finland var det däremot åtminstone lagstiftarens avsikt att omständighetsuppsåtet inte skulle vara bundet till sannolikhetsuppsåtet. Som ovan redogjorts för, är det en annan sak om själva lagen, dvs SL 4:1, tillåter efterkommandet av dylik lagstiftarvilja.

Under tematiken omständighetsuppsåt hör också ett av de mest intressanta fenomenen inom nordisk doluslära, nämligen dolus Alexanderson. Förutom sin metodiska sida (är dolusmodeller bara arbetshypoteser?) prövar det våra uppsåtsläror med en intressant falltyp: är det uppsåt när man förstår att den relevanta omständigheten alldeles väl kan vara förhanden men med vett och vilja undviker vetskap om saken för att inte riskera ansvar? Användningen av hypotetisk viljeteori och väl också sannolikhetsuppsåt skulle inte leda till uppsåtsansvar. I Finland har man åtminstone beträffande ekonomisk brottslighet, som ovan framgått, opererat med den någorlunda besläktade plikten att ta reda på (eller också plikten att vara medveten om), men det återstår att se hur den nya SL 4:1 förhåller sig till sådant. I Danmark torde dolus Alexanderson anses kunna konstituera uppsåt. ${ }^{18}$ 
Beteckningen dolus Alexanderson går tillbaka på ett fall, NJA 1941 s. 466, där det var fråga om uppsåt i förhållande till sexpartnerns ålder. Det är överhuvudtaget intressant hur man i Norden reglerat tillräkenbarhetskravet här. I Sverige slopades i och med $\mathrm{BrB}$ uppsåtskravet här och man införde i stället ett slags culparekvisit (BrB 6:9, numera 6:13). Inte heller i Norge (strl 195-196 §) eller Danmark (strl 226 §) krävs här uppsåt för ansvar $^{19}$. I Finland har man däremot inte sänkt tillräknandekravet, ett försök gjordes i samband med den näst nyaste revisionen av sexualbrottskapitlet (SL kap 20) ${ }^{20}$.

Villfarelsernas behandling i de nordiska länderna har gemensamma grunder såtillvida, att faktavillfarelser vanligen utesluter uppsåtsansvar, medan villfarelse eller okunnighet om gärningens straffbarhet (rättstridighet) bara sällan eller principiellt inte (Danmark) leder till ansvarsfrihet. Lagstiftningsåtgärderna på senaste tiden torde ha lett till ökad särutveckling åtminstone på begreppslig nivå. Exempel på detta är förstärkningen av indelningen i fakta- och rättsvillfarelser i Norge och avvisande av densamma i Finland. Genom det ökande normflödet, inklusive att en stor mängd EU-regler påverkar det straffbelagda området i EU-länderna, blir villfarelseprinciperna säkerligen testade i praxis också i framtiden.

Rusets betydelse för uppsåt och villfarelse synes variera något. $\mathrm{BrB}$ har en bestämmelse om detta. Den norska straffelovens utgångspunkt är bedömningen av den på grund av ruset misstagnas gärning som om han varit nykter. I revisionen av de allmänna lärorna intogs däremot ingen paragraf om saken i finska SL. En från allmänna regler avvikande särbehandling av berusade gärningspersoners villfarelser till deras nackdel skulle således sakna stöd i lagen. Det materiella rättsläget torde vara ungefär likadant i Danmark. ${ }^{21}$

När man diskuterar villfarelseläran kan det vara angeläget att vid sidan av fall av sådan felaktig tro som kan utesluta eller minska gärningspersonens ansvar, kort beröra också sådana situationer där gärningspersonen tror sig begå en allvarligare gärning än vad som är fallet i verkligheten. Det kan för det första vara så att någon felaktigt tror sig göra något otillåtet. Möjligt är också att man misstar sig om vad man håller på att göra. Någon t.ex. tror sig skjuta mot en människa när det i själva verket var fråga om en älg. Vid den här typen av situationer kan det påverka ansvarets omfattning vilken slags försökslära man har. En mycket subjektiv försökslära såsom den danska är ägnad att leda till försöksansvar i några dylika fall medan en mera objektiv såsom den svenska eller finska skulle vara mindre benägen att göra det. Också försöksuppsåt utgör ett intressant tema, varvid försökslärans subjektiva eller objektiva grundton spelar en roll, men denna problematik måste här förbigås.

Den gemensamma basen för de nordiska ländernas uppsåtsläror utgörs bl.a. av tudelningen i uppsåt och oaktsamhet, av utgångspunkten om att uppsåt krävs åtminstone vid strafflagsbrott med mindre också oaktsamhet stadgats straffbar samt 
av att uppsåtet inte behöver täcka gärningens straffbarhet. Det finns ett klart uppsåtsområde, nämligen avsikts- och säkerhetsuppsåt, varvid gränserna och terminologin kanske något varierar. Det finns också ett klart (subjektivt) oaktsamhetsområde, nämligen omedveten oaktsamhet. Likaså är klart att det finns medveten oaktsamhet. Riskinsikt som sådan är inte uppsåt, utan det krävs något mera. Bland gränsdragningsmodellerna har den hypotetiska viljeteorins betydelse minskat. Om det finns en motsvarande hypotetisk aspekt också vid (några former av) positiv viljeteori inklusive likgittighetsuppsåt, har diskuterats, och beror enligt min uppfattning på formens närmare uppbyggnad. Det har påpekats, att använda gränsdragningsmodeller ofta leder till likadana resultat, men klart är också, att det finns skillnader, om modellerna tas på allvar. Vad gäller djupdimensionen låter man principiellt en potentiell medvetenhet inte vara tillräcklig för uppsåt. Bevisproblematiken har inte nämnvärt diskuterats här. Den är delvis en grund- och människorättighetsfråga, vilket är ägnat att $\mathrm{i}$ viss mån främja enhetlighet på den fronten.

Genom att det nyligen skapats lagstiftning i Norden i uppsåtsrelaterade frågor, är det naturligtvis i skrivande stund inte helt klart vilka riktningar utvecklingen kommer att ta. Inte heller kan något säkert sägas om vilka frågor den nordiska uppsåtsläran kommer att rikta sitt intresse mot.

\section{Noter:}

1 Se Förhandlingarna å Det tjugoandra nordiska juristmötet i Reykjavik den 11-13 augusti 1960. København 1963 s. 113-146 samt referent Johs. Andenæs referat (bilaga V), som ger en bild av det nordiska rättsläget på den tiden. Ett jämförande verk på uppsåtets område från lite senare tid är Ross, Über den Vorsatz. Studien zur dänischen, englischen, deutschen und schwedischen Lehre und Rechtsprechung, Baden-Baden 1979.

2 Se t.ex. Jareborg, Handling och uppsåt. En undersökning rörande doluslärans underlag, Stockholm 1969 s. 210-222.

3 Åtminstone i Finland borde överhuvudtaget mera uppmärksamhet fästas vid om mentalvetenskaplig kunskap, t.ex. inom kognitiv psykologi, har någonting att erbjuda uppsåtsläran. Man kan här skilja såväl mellan den materiella och bevisrätten som mellan normbildning och normtillämpning. Enligt min uppfattning är det märkligt att expertisen har mycket stor betydelse för bedömningen av gärningspersonens tillräknelighet men spelar sällan någon roll i uppsåtssammanhang.

4 Om uppsåtet i dansk rätt se närmare t.ex. Greve, Det strafferetlige ansvar, 2. u. København 2004 s. 209-220.

5 Se t.ex. Jareborg, Allmän kriminalrätt, Uppsala 2001 s. 337-341 och Leijonhufvud - Wennberg, Straffansvar, 7. u. Stockholm 2005 s. 74-77.

6 Om svensk uppsåtspraxis se Cavallin, Skuld 2. u. Uppsala 1999 s. 279-352 och 603 ff.

7 Båda fallen har kommenterats utförligt; angående 2002 års fall se t.ex. inläggen av Asp, Träskman, Westin \& Zila, Uppsåtets nedre gräns, JT 2002-03 s. 613-639 och Cavallin, Om uppsåtsprövningen i svensk rätt efter prejudikatet NJA 2002 s. 449, JT 2003-04 s. 3-16 samt beträffande NJA 2004 s. 176 Asp, Uppsåtets nedre gräns - en efterlängtad sequel, JT 2004-05 s. 385-396 och Ulväng, Likgiltighetsuppsåt, SvJT 2005 s. 1-17.

8 Se bl.a. Ot. prp. nr. 90 (2003-2004) s. 115-118 och 226-228.

9 Om villfarelseregleringen se närmare Ot.prp. nr. 90 (2003-2004) s. 231-238 och Innst. O. nr. 72 (2004-2005) s. 54-56. För en ingående behandling av rättsvillfarelseproblematiken se Andorsen, 
Rettsvillfarelse i strafferetten, Bergen 2005. Ett äldre nordiskt verk på området är Thornstedt, Om rättsvillfarelse, Stockholm 1956.

10 Se t. ex. Mæland, Innføring i alminnelig strafferett, 3. u. Bergen 2004 s. 123-125.

11 Utlåtandet 5.3.2001 finns (på finska) i verket Avgöranden från högsta domstolen 2001 januari - juni 1-69 s. 393-439. Med beaktande av att narkotikabrotten var ett område som i den norska revisionen talade för att inkludera dolus eventualis i uppsåtsdefinitionen, kan påpekas, att finska HD hade något före sitt utlåtande, där majoriteten (4 JR) ansåg att sannolikhetsuppsåt utgör ett praktiskt och ändamålsenligt gränsdragningsinstrument, använt sannolikhetsuppsåt i narkotikafallet HD 2001:13. Ett annat avgörande, HD 2001:117, gavs senare samma år. Se också Andenæs, Alminnelig strafferett, 5. u. ved Matningsdal og Rieber-Mohn, Oslo 2004 s. 236-237.

12 I den svenskspråkiga texten har följd- och sannolikhetsuppsåt tyvärr bytt platser vid angivna ställen. Dessutom står i den svenskspråkiga texten "sänker", men i enlighet med den finskspråkiga versionen måste det tvärtom heta "höjer".

13 Om den finska utvecklingen kan den finskkunniga se Matikkala, Tahallisuudesta rikosoikeudessa, Helsinki 2005 s. 105-266.

14 Se dock HD 2002:124, som hör till de få svenskspråkiga uppsåtsprejudikaten. A hade strypt den berusade och lindrigt utvecklingsstörda $\mathrm{B}$ och därefter sparkat henne då hon satt på huk vid kanten av en brygga med påföljd att hon hade fallit i vattnet och drunknat. Majoriteten fann att A måste ha förstått att följden av hans förfarande högst sannolikt var B:s död. En ledamot yttrade, att trots att $\mathrm{A}$ inte med säkerhet kunde veta om B var simkunnig, talade av ledamoten anförda faktorer (t.ex. att man inte kan förflytta en vuxen människa särskilt långt från stranden med bara en spark) för att $\mathrm{A}$ hade kunnat anse det sannolikare att B räddar sig i land än att hon drunknar.

15 "Övervägande sannolik" var den svenska motsvarigheten till "varsin todennäköinen" redan i RP 44/2002:s SL 3:6. Det var knappast en översättningsmiss. Jag tog därvid också själva del i e-post-diskussionen om saken och framförde som min åsikt, att om man verkligen vill ha "snarare p än icke-p" (dvs enkelt sannolikhetsuppsåt för mig) rekommenderar jag "övervägande sannolik", eftersom man då vid sidan av det väldigt vaga finska uttrycket "varsin todennäköinen" åtminstone i den svenska lagtexten skulle ha en ordalydelse som på ett träffande sätt uttrycker det man är ute efter.

16 Se Frändes försök att balansera mellan lagutskottets syfte och ordalydelsen i SL 4:1 i Frände, Allmän straffrätt, 3. u. Helsingfors 2004 s. 136-141 samt Matikkala a. a. s. 29-30, 244-251 och 523-525.

17 Finska HD har på grund av revisionen och kodifieringen av de allmänna lärorna sedan 2004 bort ta ställning till många frågor inom de allmänna lärorna. Redan på grund av propositionens (RP 44/2002) växlande kvalitet måste man avråda från att bara nöja sig med att hänvisa till vad som sägs i den.

18 Se närmare Alexanderson, Tillämpning av läran om dolus eventualis, SvJT 1945 s. 295-297, Waaben, Det kriminelle forsæt, 2. o. København 1973 s. 157-159, 162 och 173, Jareborg, Allmän kriminalrätt s. 313 och 328, Greve, Det strafferetlige ansvar, 2. u. København 2004 s. 213-214, Greve - Jensen - Toftegaard Nielsen, Kommenteret straffelov. Almindelig del, 8. u. København 2004 s. 185-186 och Toftegaard Nielsen, Strafferet I. Ansvaret, 2. u. København 2004 s. 78-79.

19 Av stort principiellt intresse är Rt 2005 s. 833, där Høyesterett ansåg, att oskuldspresumtionen i den Europeiska människorättskonventionens artikel 6.2 hindrar att använda strl $195.3 \S$ efter ordalydelse.

20 RP 52/1970 s. 9-10 där det hänvisas till motsvarande regel i BrB. Den föreslagna paragrafen ansågs likväl obehövlig; LaUB 11/1970 s. 6.

21 Se t.ex. Toftegaard Nielsen a. a. s. 81-82.

\section{Adress:}

Institut för straff- och procesrätt Helsingfors Universitet FIN-000 14 Helsingfors 